\title{
Biotransformation of ruscogenins by Cunninghamella blakesleeana NRRL 1369 and neoruscogenin by endophytic fungus Neosartorya hiratsukae
}

\author{
Özge Özçinar a , Özgür Tağ ${ }^{b}$, Hasan Yusufoglu ${ }^{c}$, Bijen Kivçak ${ }^{a}$, Erdal Bedir ${ }^{\mathrm{d}, *}$ \\ a Department of Pharmacognosy, Faculty of Pharmacy, Ege University, 35100 Bornova, Izmir, Turkey \\ ${ }^{\mathrm{b}}$ Bionorm Natural Products Production \& Marketing Corp., ITOB, 35477 Menderes, Izmir, Turkey

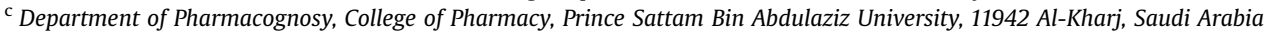 \\ d Department of Bioengineering, Faculty of Engineering, Izmir Institute of Technology, 35430 Urla, Izmir, Turkey
}

\section{A R T I C L E I N F O}

\section{Article history:}

Received 19 September 2017

Received in revised form

2 April 2018

Accepted 9 April 2018

Available online 22 April 2018

\section{Keywords:}

Microbial biotransformation

Ruscus

Ruscogenins

Neoruscogenin

Cunninghamella blakesleeana

Neosartorya hiratsukae

\begin{abstract}
A B S T R A C T
Biotransformation of steroidal ruscogenins (neoruscogenin and ruscogenin) was carried out with Cunninghamella blakesleeana NRRL 1369 and endophytic fungus Neosartorya hiratsukae yielding mainly P450 monooxygenase products together with a glycosylated compound. Fermentation of ruscogenins (75:25, neoruscogenin-ruscogenin mixture) with C. blakesleeana yielded 8 previously undescribed hydroxylated compounds. Furthermore, microbial transformation of neoruscogenin by endophytic fungus N. hiratsukae afforded three previously undescribed neoruscogenin derivatives. While hydroxylation at C-7, C-12, C-14, C-21 with further oxidation at C-1 and C-7 were observed with C. blakesleeana, $N$. hiratsukae biotransformation provided C-7 and C-12 hydroxylated compounds along with C-12 oxidized and C-1(O) glycosylated derivatives. The structures of the metabolites were elucidated by $1-\mathrm{D}\left({ }^{1} \mathrm{H},{ }^{13} \mathrm{C}\right.$ and DEPT135) and 2-D NMR (COSY, HMBC, HMQC, NOESY, ROESY) as well as HR-MS analyses.
\end{abstract}

() 2018 Elsevier Ltd. All rights reserved.

\section{Introduction}

The natural product drug discovery process involves isolation of new metabolites from natural sources, investigation of their biological activities and semi-synthesis of more active analogs. Microbial transformation plays a vital role in the preparation of new oxygenated derivatives due to the stereo- and regio-selective reaction capability (Muffler et al., 2011; Swizdor et al., 2012; Wang et al., 2015). Recently, the microbial biotransformation has been used for numerous purposes: i) to overcome the problems encountered in synthesis reactions; ii) to establish biosynthetic pathways; iii) to increase/decrease the bioactivity/toxicity profiles of the lead molecules; iv) to assist structure-activity relationship studies (Chen et al., 2010a). In addition to these, it is a useful method to model mammalian drug metabolism (Piska et al., 2016).

Metabolism of drugs is vital for the safety and efficacy, and the microbial models are advantageous due to their competences

\footnotetext{
* Corresponding author.

E-mail address: erdalbedir@iyte.edu.tr (E. Bedir).
}

enabling researchers to identify minor metabolites. It has been proven, that cytochrome P450 monooxygenase enzymes that exist in all eukaryotic microorganisms, catalyze the hydroxylation of steroidal compounds, especially Cunninghamella species (Asha and Vidyavathi, 2009; Nelson, 1999).

In recent years, endophytic organisms attract great deal of attention. They are bacterial or fungal microorganisms that colonize living internal tissues of plants without causing any disease symptoms, and they constitute one of the most exciting groups of microorganisms. While producing novel bioactive compounds, they can also interact with their hosts via special enzymes and chemicals, which would make them useful sources as biocatalysts for the biotransformation of natural products (Kumar and Ahmad, 2013; Suryanarayanan et al., 2012).

Ruscus aculeatus (Butcher's broom, Rusci rhizome, Asparagaceae) have been used traditionally against chronic venous disorders. Its extracts have strong anti-inflammatory activity, act as anti-elastase, and decrease capillary permeability (Bouskela et al., 1994; Facino et al., 1995). The major steroidal sapogenins, neoruscogenin (NR) and ruscogenin (R), namely ruscogenins as a mixture of 75:25 (NR:R), are the secondary metabolites responsible 
for aforementioned bioactivities, and they are used in clinics to treat vascular disorders such as varicose and hemorrhoid. In various pharmaceutical preparations, Ruscus dried root powders or its hydroalcoholic extracts are used in combination with phenolic compounds like trimethylhesperidin chalcone, ascorbic acid or Melilotus officinalis extract for vascular health (Boyle et al., 2003; Jawien et al., 2017). The European Pharmacopoeia prescribes not less than $1.0 \%$ of total sapogenins expressed as ruscogenins, and European Scientific Cooperative on Phytotherapy recommends oral use of 7-11 mg/day. However, there are still unknown matters in regards to the absorption of the active substances after oral administration, and whether they undergo hepatic metabolism impairing their activity at lymphatic level (EMEA, 2008; ESCOP, 2003).

Biotransformation and semi-synthesis studies performed on ruscogenins have so far been limited and there has been no report on neoruscogenin (Chen et al., 2010a, 2010b). The aim of this study was to estimate metabolism of ruscogenins and obtain new analogs deriving from neoruscogenin. Herein, we report isolation and structural elucidation of 11 previously undescribed biotransformation products of ruscogenins with diverse chemistry (Figs. 1 and 2).

\section{Results and discussion}

The literature survey prompted us to use $C$. blakesleeana as biocatalyst to predict the possible metabolism products of the major bioactive constituents of Ruscus aculeatus. Furthermore, in order to reveal the potential use of endophytes as biocatalyst, $N$. hiratsukae was used to transform neoruscogenin. After 10 days of incubation period, a number of compounds $(\mathbf{1}-\mathbf{- 1 0})$ were purified from the microbial broths, and their structures were established by 1D, 2D NMR and HRMS experiments. The ${ }^{1} \mathrm{H}$ and ${ }^{13} \mathrm{C}$ NMR spectral data of these compounds are presented in Tables $1-3$.

\subsection{Metabolite 1}

In the HR-MS of 1, the major ion peak was observed at $\mathrm{m} / \mathrm{z}$ $461.2899[\mathrm{M}+\mathrm{H}]^{+}$(calcd. 461.2903 for $\mathrm{C}_{27} \mathrm{H}_{41} \mathrm{O}_{6}$ ), indicating 8 degrees of unsaturation as in NR as well as the presence of two hydroxyl groups due to 32 amu difference. Inspection of the ${ }^{1} \mathrm{H}$ NMR spectrum revealed additional signal at $\delta 4.94$, whereas two new low-field carbon resonances appeared at $\delta 67.3$ and 86.8 in the ${ }^{13} \mathrm{C}$ NMR spectrum, which were attributed to secondary and tertiary alcohol groups based on the HSQC data. Detailed examination of the COSY spectrum led to the deduction of 4 major spin systems $(\mathrm{SS}): \mathrm{SS} 1 \rightarrow \mathrm{H}-1(\mathrm{O}) / \mathrm{H}_{2}-2 / \mathrm{H}-3(\mathrm{O}) / \mathrm{H}_{2}-4$ (A ring); $\mathrm{SS} 2 \rightarrow \mathrm{H}-6$ (olefinic) $/ \mathrm{H}-7(\mathrm{O}) / \mathrm{H}-8 / \mathrm{H}-9 / \mathrm{H}_{2}-11 / \mathrm{H}_{2}-12$ (B and $\mathrm{C}$ rings); SS3 $\rightarrow \mathrm{H}_{2}-$ $15 / \mathrm{H}-16(\mathrm{O}) / \mathrm{H}-17 / \mathrm{H}-20 / \mathrm{H}_{3}-21 ; \quad \mathrm{SS} 4 \rightarrow \mathrm{H}_{2}-23 / \mathrm{H}_{2}-24$ (allylic coupling) $/ \mathrm{H}_{2}-27$ (allylic coupling) $/ \mathrm{H}_{2}-26(\mathrm{O})$ (Fig. 3). The SS2 correlation between $\mathrm{H}-6$ ( $\delta$ 5.97) and the new resonance appeared at $\delta 4.94$ verified that the first hydroxylation was at C-7. The carbon signal at $\delta 86.8$ was readily assigned to C-14 on the basis of a longdistance correlation with the singlet methyl proton ascribed for $\mathrm{H}_{3}$ 18 ( $\delta 1.20)$ and $\mathrm{H}_{2}-15$ ( $\delta 2.47$ and 3.18) (Fig. 3). Moreover, separation of the SS2 and SS3 due to the presence of a quaternary carbon (C14) verified the position of the second hydroxyl group.

In the 2D-NOESY spectrum, the correlation of alpha oriented $\mathrm{H}-$ $9(\delta$ 2.45) with $\mathrm{H}-7$ ( $\delta$ 4.94), and H-7's correlation with the exchangeable proton of $\mathrm{C}-14(\mathrm{OH})(\delta 5.40)$ in turn, revealed the relative configuration of $\mathrm{C}-7(\mathrm{OH})$ and $\mathrm{C}-14(\mathrm{OH})$ as $\beta$ and $\alpha$, respectively (Fig. 4). Consequently, the structure of $\mathbf{1}$ was established as $7 \beta, 14 \alpha$-dihydroxy neoruscogenin.

\subsection{Metabolite 2}

The major ion peak at $\mathrm{m} / z$ 497.2531 $[\mathrm{M}+\mathrm{Na}]^{+}$(calcd. 497.2515 for $\mathrm{C}_{27} \mathrm{H}_{38} \mathrm{O}_{7} \mathrm{Na}$ ) in the HR-MS spectrum of metabolite 2 displayed 46 amu increase compared to NR. In the ${ }^{1} \mathrm{H}$ NMR spectrum of metabolite $\mathbf{2}$, the observed resonances were mostly identical with neoruscogenin, except a low-field signal at $\delta 4.80$ suggesting a hydroxylation. In the ${ }^{13} \mathrm{C}$ NMR spectrum, the chemical shift differences were more noticeable with a carbonyl signal at $201.0 \mathrm{ppm}$, and a pair of tri-substituted olefinic system signals ( $\delta 128.4$ and 165.6; deduced by HSQC and HMBC). Two additional carbon resonances in the low-field were also noticed ( $\delta 71.6$ and 86.9). The significant down-field shift for one of the aforementioned double bond resonances ( $\delta$ 165.6) suggested an alpha-beta unsaturated ketone functionality in the structure. The absence of characteristic $\mathrm{H}-6$ ( $\delta$ 6.01) and H-7 correlation in the COSY spectrum implied a

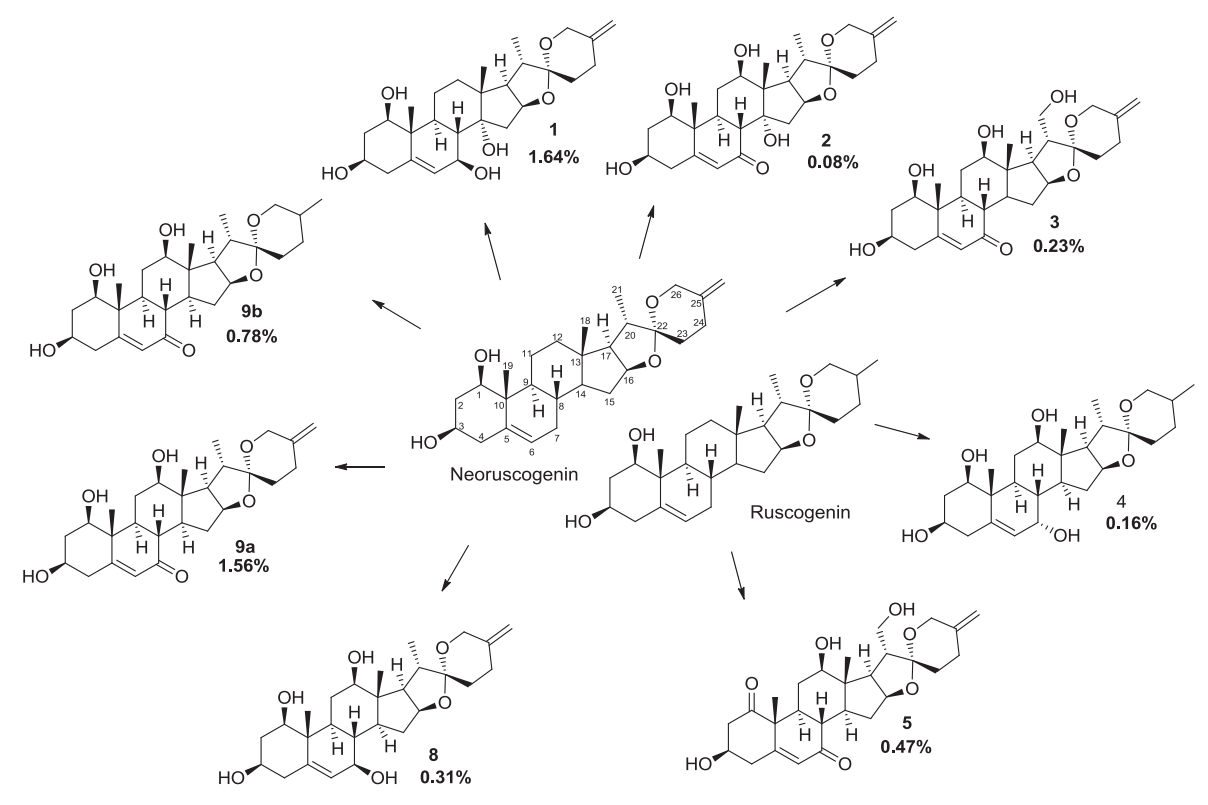

Fig. 1. Biotransformation products of ruscogenins by Cunninghamella blakesleeana. 


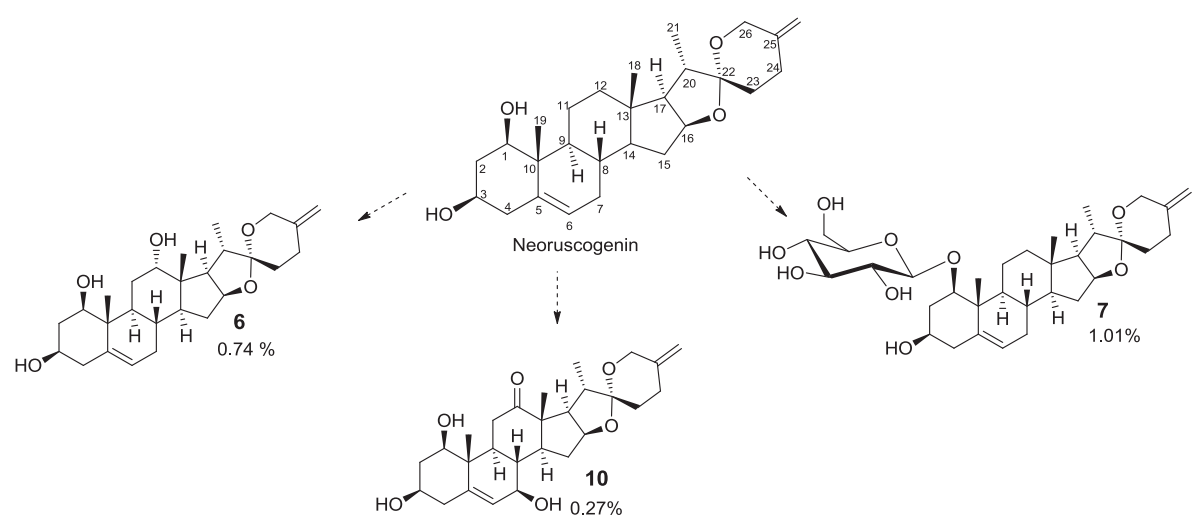

Fig. 2. Biotransformation products of neoruscogenin by Neosartorya hiratsukae.

Table 1

${ }^{1} \mathrm{H}$ - NMR data of metabolites $\mathbf{1}-\mathbf{7}$.

\begin{tabular}{|c|c|c|c|c|c|c|c|}
\hline \multirow[t]{2}{*}{ Position } & 1 & 2 & 3 & 4 & 5 & 6 & 7 \\
\hline & $\delta_{\mathrm{H}}(\mathrm{ppm}), J(\mathrm{~Hz})$ & $\delta_{\mathrm{H}}(\mathrm{ppm}), J(\mathrm{~Hz})$ & $\delta_{\mathrm{H}}(\mathrm{ppm}), J(\mathrm{~Hz})$ & $\delta_{\mathrm{H}}(\mathrm{ppm}), J(\mathrm{~Hz})$ & $\delta_{\mathrm{H}}(\mathrm{ppm}), J(\mathrm{~Hz})$ & $\delta_{\mathrm{H}}(\mathrm{ppm}), J(\mathrm{~Hz})$ & $\delta_{\mathrm{H}}(\mathrm{ppm}), J(\mathrm{~Hz})$ \\
\hline 1 & $3.82 \mathrm{~m}$ & $3.82 \mathrm{dd}(4 / 11.5)$ & $3.79 \mathrm{~m}$ & $3.81 \mathrm{~m}$ & - & $3.79 \mathrm{~m}$ & $3.92 \mathrm{~m}$ \\
\hline 2 & $2.23,2.59 \mathrm{~m}$ & $2.27 \mathrm{~m}, 2.64 \mathrm{~m}$ & $2.27 \mathrm{~m}, 2.65 \mathrm{~m}$ & $2.73 \mathrm{~m}$ & $2.94 \mathrm{~m}, 3.03 \mathrm{~m}$ & $2.21 \mathrm{~m}, 2.62 \mathrm{~m}$ & $2.12 \mathrm{~m}, 2.71 \mathrm{~m}$ \\
\hline 3 & $3.92 \mathrm{~m}$ & $3.89 \mathrm{~m}$ & $3.94 \mathrm{~m}$ & $3.97 \mathrm{~m}$ & $4.23 \mathrm{~m}$ & $3.94 \mathrm{~m}$ & $3.83 \mathrm{~m}$ \\
\hline $\begin{array}{l}4 \\
5\end{array}$ & $2.67 \mathrm{~m}$ & $2.73 \mathrm{~d}(8)$ & $2.74 \mathrm{~m}$ & $2.69 \mathrm{~m}$ & $2.94 \mathrm{~m}$ & $2.68 \mathrm{~m}$ & $2.56 \mathrm{~m}$ \\
\hline 6 & 5.97 bs & $6.01 \mathrm{~s}$ & $6.02 \mathrm{~s}$ & $6.07 \mathrm{~d}(3.6)$ & $6.03 \mathrm{~s}$ & $5.59 \mathrm{~d}(6.5)$ & $5.55 \mathrm{~d}(4.6)$ \\
\hline 7 & $4.94 \mathrm{~m}$ & & & $4.14 \mathrm{~m}$ & & $1.95 \mathrm{~m}$ & $1.84 \mathrm{~m}$ \\
\hline 8 & $2.32 \mathrm{dd}(8.8,12.0)$ & $2.97 \mathrm{~m}$ & $2.61 \mathrm{~m}$ & $1.79 \mathrm{~m}$ & $\begin{array}{l}2.59 \mathrm{dd}(11.5 / 12.0 / \\
13.0)\end{array}$ & $2.22 \mathrm{~m}$ & $1.54 \mathrm{~m}$ \\
\hline $\begin{array}{l}9 \\
10\end{array}$ & $2.45 \mathrm{~m}$ & $2.97 \mathrm{~m}$ & $1.96 \mathrm{~m}$ & $2.35 \mathrm{~m}$ & $2.37 \mathrm{~m}$ & $1.55 \mathrm{~m}$ & $1.51 \mathrm{~m}$ \\
\hline 11 & $\begin{array}{l}1.96 \mathrm{ddd}(4.0 / 4.4 / 12.8 / 13.2) \text {, } \\
2.98 \mathrm{~d}(12.8)\end{array}$ & $2.26 \mathrm{~m}, 3.34 \mathrm{~m}$ & $2.05 \mathrm{~m}, 3.25 \mathrm{~m}$ & $\begin{array}{l}2.13 \mathrm{~d}(9.2), 3.35 \mathrm{dt} \\
(3.2 / 7.2)\end{array}$ & $1.82 \mathrm{~m}, 2.38 \mathrm{~m}$ & $\begin{array}{l}2.03 \mathrm{~m}, 3.30 \mathrm{td}(5.0 / 5.5 / \\
6.0 / 17)\end{array}$ & $2.88 \mathrm{~m}, 1.38 \mathrm{~m}$ \\
\hline 12 & $1.56 \mathrm{~m}, 2.41 \mathrm{~m}$ & $4.80 \mathrm{~m}$ & $3.73 \mathrm{~m}$ & $3.79 \mathrm{~m}$ & $\begin{array}{l}3.74 \text { dd }(3.0 / 3.5 / \\
11.0)\end{array}$ & $3.68 \mathrm{~m}$ & $1.36 \mathrm{~m}, 1.65 \mathrm{~m}$ \\
\hline 13 & & & & & & & \\
\hline 14 & & & $1.71 \mathrm{~m}$ & $2.17 \mathrm{~m}$ & $1.67 \mathrm{~m}$ & $1.24 \mathrm{~m}$ & $1.13 \mathrm{~m}$ \\
\hline 15 & $3.18 \mathrm{dd}(6.4 / 7.2 / 7.2), 2.47 \mathrm{~m}$ & $\begin{array}{l}2.40 \text { ddd }(6.0 / 7.0 / \\
7.5) \\
3.60 \text { ddd }(6.0 / 7.5 / \\
7.5)\end{array}$ & $1.90 \mathrm{~m}, 3.38 \mathrm{~m}$ & $\begin{array}{l}1.71 \mathrm{~m} \\
2.65 \mathrm{~m}\end{array}$ & $\begin{array}{l}1.92 \mathrm{~m} \\
3.37 \text { dddd (6.0/7.0/ } \\
7.5)\end{array}$ & $1.63 \mathrm{~m}, 1.96 \mathrm{~m}$ & $1.42 \mathrm{~m}, 1.98 \mathrm{~m}$ \\
\hline 16 & 5.17 ddd $(7.2 / 7.2 / 7.6)$ & 5.21 ddd (7/7.5) & $4.79 \mathrm{~m}$ & 4.69 ddd $(7.5 / 7.5 / 8.0)$ & $4.77 \mathrm{~m}$ & 4.59 ddd $(9.0 / 9.0 / 10.5)$ & $4.43 \mathrm{~m}$ \\
\hline 17 & $2.81 \mathrm{dd}(6.8 / 7.6)$ & $3.14 \mathrm{~m}$ & $2.42 \mathrm{~m}$ & $2.28 \mathrm{~m}$ & $2.40 \mathrm{~m}$ & $2.18 \mathrm{~m}$ & $1.76 \mathrm{~m}$ \\
\hline 18 & $1.20 \mathrm{~s}$ & $1.34 \mathrm{~s}$ & $1.19 \mathrm{~s}$ & $1.24 \mathrm{~s}$ & $1.17 \mathrm{~s}$ & $1.15 \mathrm{~s}$ & $0.86 \mathrm{~s}$ \\
\hline 19 & $1.39 \mathrm{~s}$ & $1.48 \mathrm{~s}$ & $1.44 \mathrm{~s}$ & $1.36 \mathrm{~s}$ & $1.46 \mathrm{~s}$ & $1.34 \mathrm{~s}$ & $1.24 \mathrm{~s}$ \\
\hline 20 & $2.12 \mathrm{dd}(6.8 / 6.8)$ & $2.35 \mathrm{~m}$ & $2.53 \mathrm{~m}$ & $2.25 \mathrm{~m}$ & $2.53 \mathrm{~m}$ & $2.22 \mathrm{~m}$ & $1.91 \mathrm{~m}$ \\
\hline 21 & $1.11 \mathrm{~d}(6.8)$ & $1.44 \mathrm{~d}(7)$ & $4.12 \mathrm{~m}$ & $1.43 \mathrm{~d}(6.4)$ & $4.04 \mathrm{~m}$ & $1.38 \mathrm{~d}(6)$ & $1.03 \mathrm{~d}(6.5)$ \\
\hline 22 & & & & & & & \\
\hline 23 & $1.83 \mathrm{~m}$ & $1.83 \mathrm{~m}$ & $1.87 \mathrm{~m}$ & $1.81 \mathrm{~m}$ & $1.86 \mathrm{~m}$ & $1.81 \mathrm{~m}$ & $1.85 \mathrm{~m}$ \\
\hline 24 & $2.25 \mathrm{~m}, 2.73 \mathrm{~m}$ & $2.26 \mathrm{~m}, 2.73 \mathrm{~d}(8)$ & $2.22 \mathrm{~m}, 2.66 \mathrm{~m}$ & $1.72 \mathrm{~m}$ & $2.19 \mathrm{~m}, 2.66 \mathrm{~m}$ & $2.25 \mathrm{~m}, 2.73 \mathrm{~m}$ & $2.23 \mathrm{~m}, 2.67 \mathrm{~m}$ \\
\hline 25 & & & & $1.56 \mathrm{~m}$ & & & \\
\hline 26 & $3.96 \mathrm{~d}(12), 4.42 \mathrm{~d}(12)$ & $\begin{array}{l}4.00 \mathrm{~d}(12.5), 4.45 \mathrm{~d} \\
(7.0)\end{array}$ & $\begin{array}{l}3.95 \mathrm{~d}(12), 4.42 \mathrm{~d} \\
(12)\end{array}$ & $3.54 \mathrm{~m}, 3.69 \mathrm{~m}$ & $\begin{array}{l}3.93 \mathrm{~d}(12), 4.41 \mathrm{~d} \\
(12.5)\end{array}$ & $4.04 \mathrm{~d}(12), 4.49 \mathrm{~d}(12)$ & $\begin{array}{l}4.03 \mathrm{~d}(12), 4.44 \mathrm{~d} \\
(12)\end{array}$ \\
\hline 27 & $4.75 \mathrm{~d}(4.8)$ & $4.77 \mathrm{~d}(10.5)$ & $4.75 \mathrm{~s}, 4.79 \mathrm{~s}$ & $0.65 \mathrm{~d}(4.4)$ & $4.74,4.77 \mathrm{~s}$ & $4.77 \mathrm{~s}, 4.80 \mathrm{~s}$ & $4.79 \mathrm{~s}, 4.80 \mathrm{~s}$ \\
\hline $1^{\prime}$ & & & & & & & $4.95 \mathrm{~d}(8)$ \\
\hline $2^{\prime}$ & & & & & & & $4.03 \mathrm{dd}(7.5 / 9.5)$ \\
\hline $3^{\prime}$ & & & & & & & $4.23 \mathrm{t}(7.5 / 9)$ \\
\hline $4^{\prime}$ & & & & & & & $4.13 \mathrm{t}(9 / 9.5)$ \\
\hline $5^{\prime}$ & & & & & & & $3.93 \mathrm{~m}$ \\
\hline $6^{\prime}$ & & & & & & & $\begin{array}{l}4.33 \mathrm{~m}, 4.57 \mathrm{dd}(3 / \\
11.5)\end{array}$ \\
\hline
\end{tabular}

conjugated system formed on the ring B $(-\mathrm{C} 5=\mathrm{C} 6-\mathrm{C} 7(=\mathrm{O})-)$. Based on the DEPT 135 and HSQC spectra, it was inferred that the $\delta 86.9$ signal was a quaternary carbon, whereas the 71.6 resonance was a methine correlating with a proton at $\delta 4.80$. The planar structure of 2 was deduced by detailed inspection of the HMBC spectrum. The ${ }^{3} \mathrm{~J}_{\mathrm{H}-\mathrm{C}}$ correlations of $\mathrm{H}_{3}-18(\delta 1.34)$ with C-17 $(\delta 58.2), \mathrm{C}-13(\delta 50.8)$ and two oxygenated carbon signals at $\delta 71.6$ and 86.9 , helped us to locate the hydroxyl groups at C-12 and C-14, respectively. In the HMBC spectrum, the ketone signal at $\delta 201.0$ displayed a correlation with $\delta 2.97$ resonance. In the HSQC spectrum, $\delta 2.97$ proton corresponded with a carbon signal at $\delta 45.2$, which was attributed to C9 based on its long-range correlation with $\mathrm{H}_{3}-19$ ( $\delta$ 1.48). Thus, as suggested above, the carbonyl group was located at C-7. Inspecting 2D-NOESY spectrum and comparing 2's carbon NMR data with 


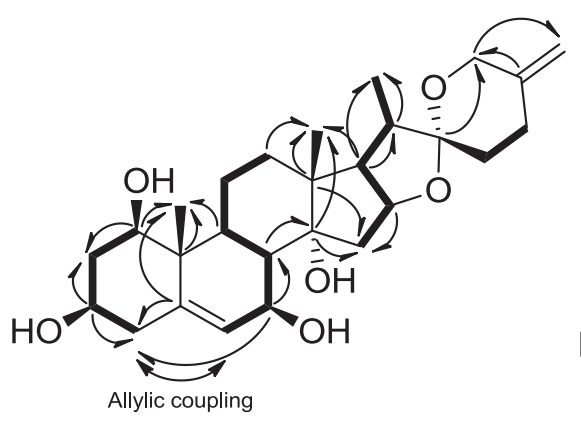

1

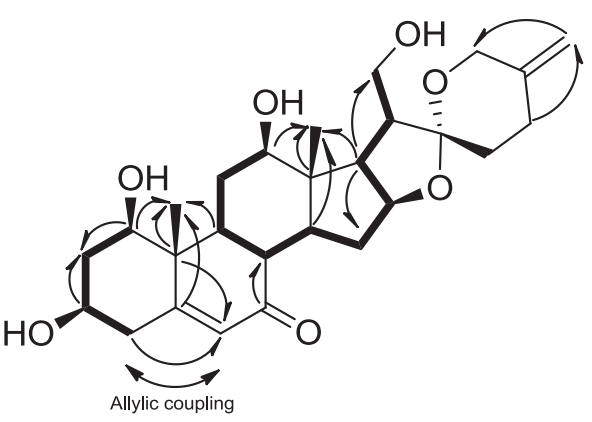

3

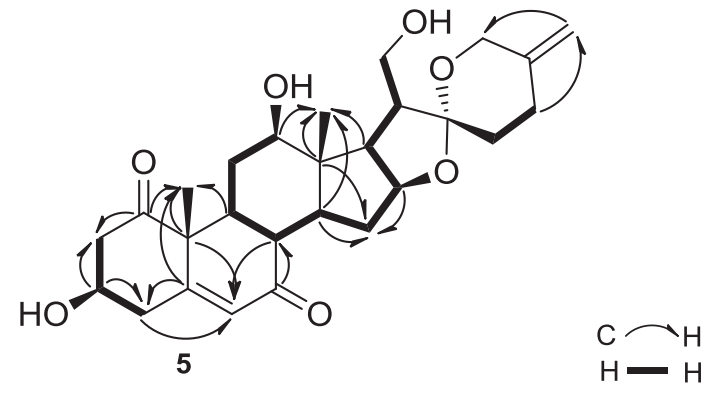

Fig. 3. COSY and key HMBC correlations of metabolites $\mathbf{1}, \mathbf{3}$ and $\mathbf{5}$.

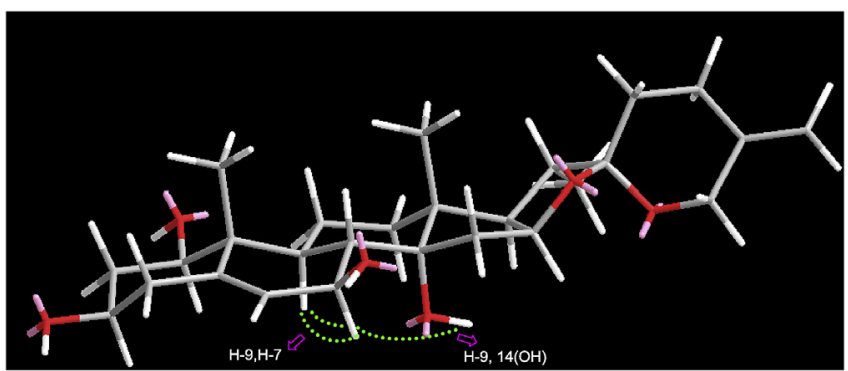

Fig. 4. Minimized energy conformer of metabolite $\mathbf{1}$ and key nOe correlations.

those of established metabolites assisted us to deduce relative configurations of the oxygenated positions. The absence of a correlation between the $\beta$-oriented $\mathrm{H}_{3}-18$ (in 31.34 ) and $\mathrm{H}-12$ (in 3 4.80 ) indicated that $\mathrm{C}-12(\mathrm{OH})$ was $\beta$-oriented, whereas the identical C-14 data of metabolites 1 and 2 (in 386.8 and 86.9, respectively) revealed an alpha configuration for $\mathrm{C}-14(\mathrm{OH})$. Consequently metabolite 2 was elucidated as $12 \beta, 14 \alpha$-dihydroxy neoruscogenin7-one.

\subsection{Metabolite 3}

The molecular formula was found to be $\mathrm{C}_{27} \mathrm{H}_{38} \mathrm{O}_{7}$ based on the major ion peak at $\mathrm{m} / \mathrm{z} 497.2509[\mathrm{M}+\mathrm{Na}]^{+}$(calcd. 497.2515 for $\mathrm{C}_{27} \mathrm{H}_{38} \mathrm{O}_{7} \mathrm{Na}$ ). Initial inspection of the ${ }^{1} \mathrm{H}$ NMR spectrum of 3 revealed the absence of characteristic secondary $\mathrm{CH}_{3}-21$ resonance as well as appearance of two down-field signals at $\delta 4.12(2 \mathrm{H})$ and $3.73(1 \mathrm{H})$. The HSQC spectrum showed a ${ }^{1} J_{\mathrm{C}-\mathrm{H}}$ correlation between the $\delta 4.12$ signal and a methylene-type carbon at $\delta 63.2$, suggesting hydroxylation of $\mathrm{C}-21$ to afford an oxymethylene group extending from $\mathrm{C}-20$. In the ${ }^{13} \mathrm{C}$ NMR spectrum of $\mathbf{3}$, the identical resonances
( $\delta$ 201.4, 164.4 and 127.6) in comparison to 2 suggested an $\alpha, \beta$ unsaturated carbonyl system of C-5, C-6 and C-7, which was further confirmed by H-6's ( $\delta$ 6.02) characteristic down-field shift (ca. $0.4 \mathrm{ppm}$ ). The new oxymethine signal at $78.4 \mathrm{ppm}$ showed ${ }^{3} J_{\mathrm{H}-\mathrm{C}}$ long-distance correlation with the singlet methyl proton of $\mathrm{H}_{3}-18$ ( $\delta$ 1.19 ) in the HMBC spectrum, assisting us to locate the other hydroxyl group at C-12 (Fig. 3). Moreover, the hydroxyl group at C-21 was also confirmed with the key HMBC's between C-17, C-20 and $\mathrm{H}_{2}-21$, and $\mathrm{C}-21$ to $\mathrm{H}-17$. In the NOESY spectrum, $\mathrm{H}-12(\delta 3.73)$ displayed correlations with alpha-oriented $\mathrm{H}-14(\delta 1.71)$ and $\mathrm{H}-17$ ( $\delta 2.42$ ), establishing $\beta$-configuration of $\mathrm{C}-12(\mathrm{OH})$. In conclusion, the structure of metabolite 3 was determined to be $12 \beta, 21$ dihydroxy neoruscogenin-7-one.

\subsection{Metabolite 4}

In the ${ }^{1} \mathrm{H}$ NMR spectrum of metabolite 4; disappearance of characteristic H-26 and H-27 signals of NR in the low-field, and observation of a new methyl signal in the down-field region $(\delta 0.65)$ implied that the compound was a ruscogenin derivative. Correspondingly, loss of the characteristic olefinic signals (C-25 and C27) of neoruscogenin with an additional methyl resonance at $17.1 \mathrm{ppm}$ in the ${ }^{13} \mathrm{C}$ NMR spectrum, and the major ion peak at $\mathrm{m} / \mathrm{z}$ $463.3059[\mathrm{M}+\mathrm{H}]^{+}(463.3060$ calcd.) in the HR-MS spectrum substantiated our first impression of $\mathbf{4}$ being a ruscogenin metabolite. The mass data exhibiting 32 amu increase over ruscogenin, and appearance of two additional carbon signals at $\delta 79.1,64.2$ suggested hydroxylations. In the HMBC spectrum, the ${ }^{3} J_{\mathrm{H}-\mathrm{C}}$ correlations of characteristic $\mathrm{H}_{3}-18$ resonance $(\delta 1.24)$ with $\mathrm{C}-13$ (45.5), C-14 (49.0), C-17 (62.9) and the new signal at $\delta 79.1$ (C-12) verified the position of first hydroxylation at $\mathrm{C}-12$. In the COSY spectrum, a strong correlation from olefinic signal at $\delta 6.07$ (H-6) with the new resonance at $\delta 4.14(\mathrm{H}-7)$ helped us to locate the second hydroxyl 
group at C-7. To determine the relative stereochemistry of $4,2 \mathrm{D}-$ NOESY and ROESY spectra were inspected. The correlation of $\mathrm{H}-12$ with alpha oriented $\mathrm{H}-9(\delta 2.35)$, and a cross peak between $\mathrm{H}-7$ and beta oriented $\mathrm{H}-8(\delta 1.79)$ revealed the configurations of $\mathrm{OH}$ groups. As a result, metabolite 4 was established as $7 \alpha, 12 \beta$-dihydroxy ruscogenin.

\subsection{Metabolite $\mathbf{5}$}

The molecular formula of 5 was determined to be $\mathrm{C}_{27} \mathrm{H}_{36} \mathrm{O}_{7}$ based on the major ion peak at $m / z 495.2363[\mathrm{M}+\mathrm{Na}]^{+}$. In the ${ }^{1} \mathrm{H}$ NMR spectrum of $\mathbf{5}$, together with characteristic NR signals, three additional low-field proton signals $(\delta 4.23,4.04,3.74)$ were observed. The disappearance of distinctive secondary methyl group (C-21) was also noticed readily as in metabolite 3 . Besides, ${ }^{13} \mathrm{C}$ NMR and DEPT135 revealed extra signals in the low-field: two carbonyl resonances $(\delta 208.2,199.7)$, an oxymethine $(\delta 77.8)$ and an oxymethylene $(\delta 63.2)$. On the basis of these data, it was evident that, C-21 and an additional position were hydroxylated on the NR framework. Ketone formation at $\mathrm{C}-7$ position was clear due to deshielding of H-6 ( $\delta$ 6.03) and C-5 ( $\delta$ 159.8). However, C-5's ca. 5 ppm up-field shift compared to those of 2 and 3 implied an alteration on the ring A. In the HMBC spectrum (Fig. 3), strong ${ }^{3} \mathrm{~J}_{\mathrm{H}-\mathrm{C}}$ correlations of $\mathrm{H}_{3}-19(\delta 1.46)$ with $\delta 208.2, \mathrm{C}-5(\delta 159.8), \mathrm{C}-9(\delta 42.1)$ and $\mathrm{C}-10(\delta$ 54.2) signals suggested oxidation of the secondary alcohol at $\mathrm{C}-1$, whereas the correlation of $\mathrm{H}_{3}-18(\delta$ 1.17) with the new oxygenated methine carbon at $\delta 77.8$ implied the second hydroxylation position as $\mathrm{C}-12$. All of these deductions were also verified by establishing the spin systems of metabolite $\mathbf{5}$ via examination of the COSY, TOCSY and HSQC spectra: SS1 $\rightarrow \mathrm{H}_{2}-2 / \mathrm{H}-$ $3(\mathrm{O}) / \mathrm{H}_{2}-4$ (A ring); SS2 $\rightarrow \mathrm{H}-12(\mathrm{O}) / \mathrm{H}-11 / \mathrm{H}-9 / \mathrm{H}-8 / \mathrm{H}-14 / \mathrm{H}_{2}-15 / \mathrm{H}-$ $16(\mathrm{O}) / \mathrm{H}-17 / \mathrm{H}-20 / \mathrm{H}_{2}-21 ; \mathrm{SS} 3 \rightarrow \mathrm{H}_{2}-23 / \mathrm{H}_{2}-24 \mathrm{SS} 4 \rightarrow \mathrm{H}_{2}-27$ (allylic coupling $/ \mathrm{H}_{2}-26(\mathrm{O})$. The stereochemistry of the hydroxyl group at C-12 was determined by examining the NOESY and ROESY spectra, which exhibited a cross peak from alpha oriented $\mathrm{H}-14(\delta 1.67)$ to $\mathrm{H}-12(\delta 3.74)$ confirming the orientation of $\mathrm{C}-12(\mathrm{OH})$ as beta. On the basis of these evidence, the structure of compound $\mathbf{5}$ was elucidated as 12ß,21-dihydroxy neoruscogenin-1,7-dione.

Metabolites $\mathbf{6}$ and $\mathbf{7}$ were obtained from the biotransformation study of $N$. hiratsukae.

\subsection{Metabolite 6}

The HR-MS spectrum of $\mathbf{6}$ provided a major ion peak at $\mathrm{m} / \mathrm{z}$ 445.2949, indicating $16 \mathrm{amu}$ increase over NR. In the ${ }^{1} \mathrm{H}$ NMR spectrum of $\mathbf{6}$, in addition to the characteristic low-field signals of neoruscogenin, an additional resonance at $\delta 3.68$ was observed (Table 2). In the ${ }^{13} \mathrm{C}$ NMR and DEPT135 spectra, the additional oxymethine signal at $\delta 79.3$ undoubtedly demonstrated monohydroxylation on the skeleton, while a key HMBC between the new oxymethine carbon signal and $\mathrm{H}_{3}-18$ methyl group $(\delta 1.15)$ helped us locating the hydroxyl group at $\mathrm{C}-12$. The relative configuration at the new stereocenter was established based on the NOESY data, displaying correlations between $\mathrm{H}-12(\delta 3.68)$ and $\beta$-oriented $\mathrm{H}_{3}$ $18 / \mathrm{H}-20$ protons ( $\delta 1.15$ and 2.22 , respectively). Consequently, the structure of $\mathbf{6}$ was determined to be $12 \alpha$-hydroxy neoruscogenin.

\subsection{Metabolite 7}

In the HR-MS of 7, the major ion peak was observed at $m / z$ $613.3353[\mathrm{M}+\mathrm{Na}]^{+}$(calcd. 613.3353 for $\mathrm{C}_{33} \mathrm{H}_{50} \mathrm{O}{ }_{9} \mathrm{Na}$ ), which was suggesting glycosidation of the neoruscogenin skeleton due to 162 amu difference $\left(\mathrm{C}_{6} \mathrm{H}_{10} \mathrm{O}_{5}\right)$. Inspection of the ${ }^{1} \mathrm{H}$ NMR spectrum revealed an anomeric proton at $\delta 4.95(\mathrm{~d}, J=8.0 \mathrm{~Hz})$, whereas the additional resonances in the ${ }^{13} \mathrm{C}$ NMR spectrum deriving from a hexose unit were consistent with the presence of a $\beta$-glucopyranose moiety. Comparing the spectral data of $\mathbf{7}$ with neoruscogenin and the other metabolites, the significant down-field shift of C-1 $(\delta$ 82.9, $\Delta_{\mathrm{ppm}}=6-8$ ) helped us locating the glucopyranose unit. Additionally, the ${ }^{3} J_{\mathrm{H}-\mathrm{C}}$ correlation of $\mathrm{C}-1(\delta 82.9)$ with the anomeric proton signal $(\delta 4.95)$ in the HMBC spectrum verified the glycosidation site as $\mathrm{C}-1$. On the basis of these results, the structure of 7 was established as neoruscogenin-1-O- $\beta$-glucopyranoside.

\subsection{Metabolites $\mathbf{8}, \mathbf{9 a}, \mathbf{9 b}$ and $\mathbf{1 0}$}

Metabolites 8-10 were not brought to a good state of purity due to purification difficulties. However, the structures of these metabolites were identified based on detailed inspection of 1- and 2D NMR spectra.

The major ion peak at $m / z 483.2717[\mathrm{M}+\mathrm{Na}]^{+}$in the HR-MS spectrum of metabolite 8 displayed 32 amu increase over NR, suggesting a dihydroxy analog. In the low-field region of the ${ }^{1} \mathrm{H}$ NMR spectrum, two additional low-field protons ( $\delta 3.27$ and 3.65) were observed (Table 3). Besides, in the ${ }^{13} \mathrm{C}$ NMR spectrum, two extra down-field carbon signals at $\delta 72.7$ and 80.3 were also noted. In order to deduce oxidation positions, the 2D NMR spectra were inspected in detail. Full assignments of the proton and carbon signals of $\mathbf{8}$ secured by the COSY and HSQC spectra implied the position of hydroxylations as C-7 and C-12. In the HMBC spectrum, the long-range correlations of the olefinic carbon signals at 141.4 and $130.9 \mathrm{ppm}$ (C-5 and C-6, respectively) with $\mathrm{H}-7$ ( $\delta 3.65)$, and C12 ( $\delta$ 80.3) and $\mathrm{H}_{3}-18\left(\begin{array}{l}0.81\end{array}\right)$ verified the proposed transformations. For establishing stereochemistry of $\mathbf{8}$, a 2D-NOESY experiment was performed. Alpha oriented H-9 $(\delta 1.35)$ exhibited correlations with $\mathrm{H}-7$ ( $\delta 3.65)$ and $\mathrm{H}-12(\delta 3.27)$, while $\mathrm{H}-17 \alpha(\delta$ 1.87) correlated with $\mathrm{H}-12$, substantiating co-facial orientation of $\mathrm{C}-7$ and $\mathrm{C}-12 \mathrm{OH}$ groups as $\beta$. Based on these findings, the structure of 8 was determined as $7 \beta, 12 \beta$-dihydroxy neoruscogenin. In the ${ }^{1} \mathrm{H}$ NMR spectrum of $\mathbf{9}$, appearance of two distinctive $\mathrm{H}-16$ signals and presence of characteristic methyl resonances for both starting frameworks ( $R$ and NR) point to a mixture of two metabolites, NR being the major one $(\mathbf{9 a})$. In the ${ }^{13} \mathrm{C}$ NMR spectrum, similar with metabolite 4, a weak methyl resonance at $16.2 \mathrm{ppm}$ was attributed to the $\mathrm{C}-27$ of the minor ruscogenin metabolite $(\mathbf{9 b})$. These suggestions were also substantiated with a major peak at $m / z 459.2732$ $[\mathrm{M}+\mathrm{H}]^{+}$and a minor peak at $461.3885[\mathrm{M}+\mathrm{H}]^{+}$in the HR-MS spectrum, indicating 30 amu difference compared to NR and R, respectively. All the proton and carbon resonances of metabolite $\mathbf{9 a}$ were secured by COSY, HSQC and HMBC spectra, verifying C-12 hydroxylation as in $\mathbf{2}-\mathbf{5}$ and $\mathbf{8}$, and oxidation of $\mathrm{C}-7$ to give ketone functionality as in compounds $\mathbf{2}, \mathbf{3}$ and $\mathbf{5}$. In the case of stereochemical assignment of $\mathrm{C}-12(\mathrm{OH})$, the chemical shift and coupling constant values obtained for metabolite $\mathbf{1}$ and $\mathbf{9 a}$ were taken into consideration, revealing same configuration for both compounds as beta for the hydroxyl group. This suggestion was also substantiated with the nOe correlation of $\mathrm{H}-12(\delta 3.25)$ and alpha oriented $\mathrm{H}-9(\delta$ 1.79 ), $\mathrm{H}-14(\delta 1.41)$ and $\mathrm{H}-17$ ( $\delta 1.84)$ resonances in the 2D-NOESY spectrum. When the $1 \mathrm{D}$ and 2D-NMR spectra were also inspected for the minor constituent $\mathbf{9 b}$, completely identical structural conclusions were achieved for ruscogenin skeleton. Consequently, metabolites 9a and 9b were elucidated as 12 3 -hydroxy neoruscogenin-7-one and $12 \beta$-hydroxy ruscogenin-7-one, respectively. The HR-MS spectrum of $\mathbf{1 0}$ provided a major peak at $\mathrm{m} / \mathrm{z}$ 481.2566, $[\mathrm{M}+\mathrm{Na}]^{+}$(calcd. 481.2566), supporting a molecular formula of $\mathrm{C}_{27} \mathrm{H}_{38} \mathrm{O}_{6} \mathrm{Na}$. In the ${ }^{1} \mathrm{H}$ NMR spectrum, in addition to typical neoruscogenin signals, the appearance of a proton resonance at $\delta 4.09$, which was correlating with $\delta 70.6$ resonance in the HSQC spectrum, implied transformation of a methylene carbon to oxymethine carbon via hydroxylation in the steroid framework. This 
Table 2

${ }^{13} \mathrm{C}$ NMR data of metabolites $\mathbf{1}-\mathbf{7}$.

\begin{tabular}{|c|c|c|c|c|c|c|c|}
\hline \multirow[t]{2}{*}{ Position } & 1 & 2 & 3 & 4 & 5 & 6 & 7 \\
\hline & $\delta_{\mathrm{c}}(\mathrm{ppm})$ & $\delta_{\mathrm{H}}(\mathrm{ppm})$ & $\delta_{\mathrm{H}}(\mathrm{ppm})$ & $\delta_{\mathrm{H}}(\mathrm{ppm})$ & $\delta_{\mathrm{H}}(\mathrm{ppm})$ & $\delta_{\mathrm{c}}(\mathrm{ppm})$ & $\delta_{\mathrm{c}}(\mathrm{ppm})$ \\
\hline 1 & 78.3 & 76.2 & 76.3 & 77.4 & 208.2 & 77.8 & 82.9 \\
\hline 2 & 43.9 & 42.9 & 42.7 & 43.4 & 48.2 & 43.2 & 37.3 \\
\hline 3 & 68.2 & 66.1 & 66.3 & 67.3 & 66.6 & 67.9 & 67.8 \\
\hline 4 & 43.9 & 43.3 & 43.4 & 44.2 & 41.5 & 43.6 & 43.2 \\
\hline 5 & 140.7 & 165.6 & 164.4 & 142.9 & 159.8 & 140.1 & 139.2 \\
\hline 6 & 132.1 & 128.4 & 127.6 & 128.1 & 127.5 & 124.2 & 124.7 \\
\hline 7 & 67.3 & 201.0 & 201.4 & 64.2 & 199.7 & 31.9 & 31.7 \\
\hline 8 & 45.7 & 48.9 & 44.7 & 37.7 & 43.9 & 42.7 & 32.8 \\
\hline 9 & 43.9 & 45.2 & 49.6 & 42.7 & 42.1 & 50.6 & 50.1 \\
\hline 10 & 44.1 & 45.2 & 45.2 & 43.5 & 54.2 & 43.5 & 42.3 \\
\hline 11 & 24.0 & 33.6 & 30.6 & 34.1 & 30.7 & 34.2 & 23.8 \\
\hline 12 & 33.1 & 71.6 & 78.4 & 79.1 & 77.8 & 79.3 & 40.0 \\
\hline 13 & 46.0 & 50.8 & 46.4 & 45.5 & 47.1 & 45.7 & 40.0 \\
\hline 14 & 86.8 & 86.9 & 48.8 & 49.0 & 49.0 & 55.2 & 55.8 \\
\hline 15 & 43.4 & 42.1 & 32.2 & 31.7 & 33.6 & 31.9 & 32.1 \\
\hline 16 & 83.1 & 82.5 & 82.6 & 81.1 & 82.4 & 81.3 & 81.2 \\
\hline 17 & 59.9 & 58.2 & 59.4 & 62.9 & 59.4 & 62.8 & 62.8 \\
\hline 18 & 20.7 & 14.0 & 11.0 & 11.3 & 10.9 & 11.1 & 10.9 \\
\hline 19 & 13.9 & 12.0 & 11.7 & 12.6 & 16.8 & 13.7 & 14.0 \\
\hline 20 & 42.4 & 42.9 & 50.2 & 42.7 & 59.6 & 42.7 & 41.7 \\
\hline 21 & 15.7 & 14.5 & 63.2 & 14.2 & 63.2 & 14.1 & 14.6 \\
\hline 22 & 110.1 & 109.9 & 108.9 & 109.3 & 109.2 & 109.5 & 109.4 \\
\hline 23 & 33.8 & 33.2 & 33.8 & 30.4 & 33.6 & 33.1 & 31.8 \\
\hline 24 & 29.4 & 28.8 & 29.4 & 31.7 & 28.6 & 28.8 & 28.9 \\
\hline 25 & 144.9 & 144.3 & 142.2 & 29.0 & 143.8 & 144.3 & 144.2 \\
\hline 26 & 65.3 & 64.7 & 63.1 & 73.8 & 64.5 & 64.8 & 63.4 \\
\hline 27 & 108.9 & 108.5 & 109.0 & 17.1 & 108.8 & 108.4 & 108.5 \\
\hline $1^{\prime}$ & & & & & & & 101.2 \\
\hline $2^{\prime}$ & & & & & & & 75.2 \\
\hline $3^{\prime}$ & & & & & & & 78.3 \\
\hline $4^{\prime}$ & & & & & & & 72.1 \\
\hline $5^{\prime}$ & & & & & & & 77.9 \\
\hline $6^{\prime}$ & & & & & & & 63.4 \\
\hline
\end{tabular}

new low-field proton was ascribed to $\mathrm{H}-7$ on the basis of its correlation to characteristic olefinic signal of H-6 ( $\delta 5.93)$ in the COSY spectrum. As well, a carbonyl signal at $\delta 213.3$, which was lacking in the ${ }^{13} \mathrm{C}$ NMR spectrum due to its low intensity, displayed a strong long-range correlation with the methyl resonance at $\delta 1.20$. The latter was assigned to $\mathrm{H}_{3}-18$ because of its long-range correlation to $\mathrm{C}-17$, which also exhibited ${ }^{3} J_{\mathrm{H}-\mathrm{C}}$ correlation to $\mathrm{H}_{3}-21$. As a result of these key HMBC's, the position of the carbonyl group was secured as $\mathrm{C}-12$. The beta oriented hydroxyl group at C-7 was readily deduced via the correlation of alpha oriented $\mathrm{H}-14(\delta 1.92)$ with $\mathrm{H}-7$ ( $\delta 4.09$ ) in the NOESY spectrum. Thus, the structure of $\mathbf{1 0}$ was determined as $7 \beta$-hydroxy neoruscogenin 12 -one.

\section{Conclusions}

Recent studies performed on steroids showed that Cunninghamella species have high catalytic activity (Baydoun et al., 2017; Xiao et al., 2011; Xu et al., 2015), which can also be used for investigating the metabolism of drugs because of their abilities of catalyzing Phase I and II reactions similar to the mammalian enzyme systems. In continuation of our biotransformation studies performed on ruscogenins by C. blakesleeana (Özçinar et al., 2016), a number of previously unreported compounds were obtained. The compounds were mainly hydroxylation products including C-7, C$12, \mathrm{C}-14$ and $\mathrm{C}-21$ positions, whereas further oxidations at $\mathrm{C}-1$ and C-7 were encountered.

All the metabolites were C-7 hydroxylated or oxidized analogs as parallel to other studies performed on steroidal compounds (Ahmad et al., 2017; Kozlowska et al., 2017; Xu et al., 2015). This modification, catalyzed by fungal CYP450 monooxygenase and dehydrogenase enzymes, readily takes place due to the allylic nature of C-7 position (Ortiz de Montellano and Nelson, 2011). Additionally, another major hydroxylation location was C-12, except compound 1. Interestingly, this transformation was stereoselective $[12-\beta(\mathrm{OH})]$ compared to the regioselective $\mathrm{C}-7$ hydroxylation. The monooxygenation reactions occurred at the tertiary $\mathrm{C}-14$ (1 and 2) and C-21 methyl group (3 and $\mathbf{5}$ ) have been encountered rarely on steroidal framework, as non-reactive centers, they are challenging positions for modification via chemical synthesis (Faramarzi et al., 2008; Kolet et al., 2014; Lamm et al., 2007; Wu et al., 2011).

In order to exploit the catalytic capacity of the endophytic fungi to obtain new neoruscogenin derivatives, $N$. hiratsukae was utilized, providing CYP450 monooxygenase products mainly as in C. blakesleeana study. Moreover, observation of further oxidation at C-12 to yield ketone functionality (10) and the phase II metabolite 7 as glycosylated derivative were noteworthy.

Further studies are in progress with different endophytic fungi to include more compounds to the metabolite library, as well bioactivity studies are being pursued for the compounds with sufficient quantity.

\section{Experimental}

\subsection{General experimental procedures}

Mass spectrometry analysis was performed on an Agilent 1200/ 6530 Instrument -HRTOFMS. The 1D and 2D NMR spectra were obtained on Varian Oxford AS400 and Bruker DRX-500 instruments. Proton and carbon chemical shifts are relative to the solvent signals. Column chromatography experiments were carried out on silica gel 60 (40-63 mu-Merck), Sephadex LH-20 (GE 
Table 3

${ }^{1} \mathrm{H}$ and ${ }^{13} \mathrm{C}$ NMR data of metabolites 8-10.

\begin{tabular}{|c|c|c|c|c|c|c|}
\hline \multirow[t]{2}{*}{ Position } & \multicolumn{2}{|l|}{8} & \multicolumn{2}{|l|}{$9 \mathbf{a}(9 \mathbf{b})$} & \multicolumn{2}{|l|}{10} \\
\hline & $\delta_{\mathrm{H}}(\mathrm{ppm}), J(\mathrm{~Hz})$ & $\delta_{\mathrm{c}}(\mathrm{ppm})$ & $\delta_{\mathrm{H}}(\mathrm{ppm}), J(\mathrm{~Hz})$ & $\delta_{\mathrm{c}}(\mathrm{ppm})$ & $\delta_{\mathrm{H}}(\mathrm{ppm}), J(\mathrm{~Hz})$ & $\delta_{\mathrm{c}}(\mathrm{ppm})$ \\
\hline 1 & $3.38 \mathrm{~m}$ & 78.5 & 3.49 dd $(4.5 / 12)$ & 75.8 & $3.70 \mathrm{~m}$ & 76.8 \\
\hline 2 & $1.61 \mathrm{~m}, 1.97 \mathrm{~m}$ & 42.5 & $1.71 \mathrm{~m}, 2.10 \mathrm{~m}$ & 40.8 & $2.21 \mathrm{~m}, 2.60 \mathrm{~m}$ & 42.8 \\
\hline 3 & $3.44 \mathrm{~m}$ & 68.6 & $3.57 \mathrm{~m}$ & 65.8 & $3.94 \mathrm{~m}$ & 67.2 \\
\hline 4 & $2.23 \mathrm{~m}$ & 42.8 & $2.40 \mathrm{dd}(11.5 / 13.0)$ & 41.8 & $2.65 \mathrm{~m}$ & 42.9 \\
\hline 5 & & 141.4 & & 164.7 & & 104.2 \\
\hline 6 & $5.42 \mathrm{~s}$ & 130.9 & $5.80 \mathrm{~s}$ & 126.9 & $5.93 \mathrm{~s}$ & 130.7 \\
\hline 7 & $3.65 \mathrm{~d}(10.5)$ & 72.7 & & 202.6 & $4.09 \mathrm{~m}$ & 70.6 \\
\hline 8 & $1.49 \mathrm{~m}$ & 40.8 & $2.45 \mathrm{~m}$ & 44.1 & $2.23 \mathrm{~m}$ & 40.4 \\
\hline 9 & 1.35 ddd (3.6/4.4/7.6) & 48.3 & $1.79 \mathrm{~m}$ & 49.4 & $1.94 \mathrm{~m}$ & 42.3 \\
\hline 10 & & 43.8 & & 44.8 & & 50.5 \\
\hline 11 & $1.54 \mathrm{~m}, 2.51 \mathrm{~m}$ & 34.2 & $2.27 \mathrm{~m}, 2.55 \mathrm{~m}$ & 32.6 & $2.95 \mathrm{~m}, 3.66 \mathrm{~d}(5)$ & 40.3 \\
\hline 12 & 3.27 dd $(4.0 / 4.4 / 6.4)$ & 80.3 & $3.25 \mathrm{~m}$ & 77.9 & & 213.3 \\
\hline 13 & & 47.0 & & 47.7 & & 55.5 \\
\hline 14 & $1.22 \mathrm{~m}$ & 55.7 & $1.41 \mathrm{~m}$ & 29.8 & $1.92 \mathrm{~m}$ & 42.3 \\
\hline 15 & $1.66 \mathrm{~m}, 2.35 \mathrm{~m}$ & 35.0 & $1.50 \mathrm{~m}, 2.84 \mathrm{~m}$ & 32.6 & $2.25 \mathrm{~m}, 2.95 \mathrm{~m}$ & 34.5 \\
\hline 16 & 4.45 ddd, (7.2/7.6/7.2) & 82.8 & 4.51 ddd $(6.5 / 7.5 / 8.0 / 8.5)$ & 81.2 & 4.55 ddd (7.0/7.0/8.5) & 80.6 \\
\hline 17 & $1.87 \mathrm{~m}$ & 62.7 & $1.84 \mathrm{~m}$ & 60.8 & $2.85 \mathrm{~m}$ & 53.5 \\
\hline 18 & $0.81 \mathrm{~s}$ & 11.3 & $0.80 \mathrm{~s}$ & 9.7 & $1.20 \mathrm{~s}$ & 15.8 \\
\hline 19 & $1.10 \mathrm{~s}$ & 13.5 & $1.29 \mathrm{~s}$ & 10.6 & $1.31 \mathrm{~s}$ & 12.7 \\
\hline 20 & $1.91 \mathrm{~m}$ & 43.7 & $1.91 \mathrm{~m}$ & 42.3 & $1.94 \mathrm{~m}$ & 42.3 \\
\hline 21 & $1.02 \mathrm{~d}(6.1)$ & 14.0 & $1.04 \mathrm{~d}(7.5)$ & 12.8 & $1.29 \mathrm{~d}$ & 14.0 \\
\hline 22 & & 110.8 & & 109.6 & & 108.5 \\
\hline 23 & $1.74 \mathrm{~m}$ & 34.1 & $1.73 \mathrm{~m}$ & 32.6 & $1.78 \mathrm{~m}$ & 33.3 \\
\hline 24 & $2.26 \mathrm{~m}, 2.57 \mathrm{~m}$ & 29.5 & $\begin{array}{l}2.27 \mathrm{~m}, 2.55 \mathrm{~m} \\
{[1.71 \mathrm{~m}]}\end{array}$ & 28.1 & $2.24 \mathrm{~m}, 2.68 \mathrm{~m}$ & 29.4 \\
\hline 25 & & 145.3 & {$[1.62 \mathrm{~m}]$} & $143.7[28.5]$ & & 143.9 \\
\hline 26 & $3.83 \mathrm{~d}(11.8), 4.28 \mathrm{~d}(12.5)$ & 65.9 & $\begin{array}{l}3.85 \mathrm{~d}(12), 4.30 \mathrm{~d}(12) \\
{[3.37 \mathrm{~d} 11.0]} \\
{[3.48 \mathrm{dd} 4.5 / 11.7]}\end{array}$ & $64.4[66.5]$ & $4.01 \mathrm{~d}(13), 4.43 \mathrm{~d}(12)$ & 64.6 \\
\hline 27 & $4.73 \mathrm{~s}, 4.77 \mathrm{~s}$ & 108.9 & $\begin{array}{l}4.76 \mathrm{~s}, 4.79 \mathrm{~s} \\
{[0.81 \mathrm{~d} 4.1]}\end{array}$ & $107.8[16.1]$ & $4.77 \mathrm{~s}, 4.82 \mathrm{~s}$ & 109.1 \\
\hline
\end{tabular}

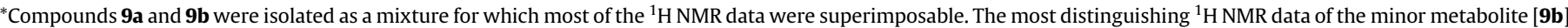
are given above.

Healthcare) and RP (C-18, 25-40 $\mu \mathrm{m})$ (Merck). TLC analyses were carried out on Silica gel 60 F254 (Merck) and RP-18 F254s (Merck) plates. Compounds were detected by UV and $20 \% \mathrm{H}_{2} \mathrm{SO}_{4}$ /water spraying reagent followed by heating at $105^{\circ} \mathrm{C}$ for $1-2 \mathrm{~min}$. Optic rotations were measured using Perkin-Elmer 341 polarimeter.

\subsection{Microorganisms and the lead compounds}

C. blakesleeana NRRL 1369 was obtained from the ARS Culture Collection, USA. Neosartoria hiratsukae, an endophytic fungus isolated from Astragalus angustifolius (Ekiz, 2016), was also selected for preparative scale biotransformation. Ruscogenins (NR to R ratio was 75:25) and neoruscogenin (>95\%) was donated by Bionorm Natural Products Ltd. (Izmir, Turkey).

\subsection{Microbial transformation procedures}

The biotransformation process was conducted at two scales analytical and preparative. Stock cultures of $C$. blakesleeana and $N$. hiratsukae stored at $+4{ }^{\circ} \mathrm{C}$ were revived on PDA (Potatodextrose-agar) slants at $30{ }^{\circ} \mathrm{C}$ and $25^{\circ} \mathrm{C}$, respectively. Inoculum of $2 \%$ derived from the suspension of 5-7 days old cultures with Tween $80(0.1 \%)$, was used in the biotransformation process. Onestage fermentation protocol was followed where ruscogenins/ neoruscogenin were fed to the biotransformation media $72 \mathrm{~h}$ after the inoculation. The biotransformation media contained $2 \%$ glucose, $0.5 \%$ yeast extract, $0.5 \% \mathrm{NaCl}, 0.5 \% \mathrm{~K}_{2} \mathrm{HPO}_{4}$ and $0.5 \%(\mathrm{w} / \mathrm{v})$ peptone (pH 6.0). Analytical scale was conducted using $250 \mathrm{ml}$ flasks containing $50 \mathrm{ml}$ of media and $10 \mathrm{mg}$ of ruscogenins. Every 2 days, samples with a volume of $0.5 \mathrm{ml}$ were taken and centrifuged. Then the supernatants were extracted with ethyl acetate. In order to differentiate the transformed products from the metabolites of the microorganisms, one flask was kept in same condition with no lead compound. In preparative scale, 1 L flasks containing $200 \mathrm{ml}$ of media and $40 \mathrm{mg}$ of substrate used in same conditions. In the C. blakesleeana NRRL 1369 study at preparative scale, $640 \mathrm{mg}$ of ruscogenins was used $\left(30^{\circ} \mathrm{C}, 180 \mathrm{rpm}, 10\right.$ days), whereas in the $N$. hiratsukae preparative experiment, $1.48 \mathrm{~g}$ of neoruscogenin was fed $\left(25^{\circ} \mathrm{C}, 180 \mathrm{rpm}, 10\right.$ days $)$.

\subsection{Extraction and isolation}

After the incubation period, separation of the microorganisms from the growth media was first step. This process was carried out by using vacuum filtration, and then the broths were extracted with both ethyl acetate ( 3 times) and $n$-butanol. Ethyl acetate extracts were dried over anhydrous sodium sulfate. Then the organic layers were combined and evaporated under vacuum. By comparing with the reference sample of ruscogenins/neoruscogenin and the blank sample, the biotranformation products were identified on thin layer chromatography (TLC) plates.

Compounds $\mathbf{1}-\mathbf{5}$ and $\mathbf{8 , 9}$ were isolated from the EtOAc extract (712 mg) of C. blakesleeana and Ruscogenins. This extract was applied to reverse phase flash column chromatography $(40 \mathrm{~g}, 5 \mathrm{ml} /$ min; 30\%; $\mathrm{ACN}: \mathrm{H}_{2} \mathrm{O}$ ), which provided 14 main fractions. Fraction $\mathrm{A}$ $(27.7 \mathrm{mg}$ ) was subjected to normal phase silica gel column (1.5/ $16 \mathrm{~cm} ; 12 \mathrm{~g}$ ) using $\mathrm{CHCl}_{3}: \mathrm{MeOH}: \mathrm{H}_{2} \mathrm{O}(95: 5: 0.5)$ for the further purifications. This afforded $2 \mathrm{mg} 1$ and $0.5 \mathrm{mg} 2$. To obtain metabolite 8, fraction $B(39 \mathrm{mg})$ was precipitated in acetonitrile to give $10.5 \mathrm{mg}$ of 8 . The supernatant was evaporated ( $22 \mathrm{mg}$ ), and was applied to open column chromatography containing normal phase silica gel $(1.5 / 14 \mathrm{~cm} ; 10 \mathrm{~g})$ with Hex:EtOAc:MeOH solvent system $(10: 10: 2)$ 
to give $1.5 \mathrm{mg}$ of $\mathbf{3}$ and $1 \mathrm{mg}$ of $\mathbf{4}$. Fraction $\mathrm{C}(63 \mathrm{mg})$ was subjected to silica gel $(2 / 13 \mathrm{~cm} ; 15 \mathrm{~g})$ eluting with $\mathrm{CHCl}_{3}: \mathrm{MeOH}(90: 10)$ to give $15 \mathrm{mg}$ of $\mathbf{9}$ (mixture of $\mathbf{9 a}$ and $\mathbf{9 b}$ ), and $3 \mathrm{mg}$ of $\mathbf{5}$. Compounds $\mathbf{6}$, $\mathbf{7}$ and $\mathbf{1 0}$ were isolated from the combined EtOAc and $\mathrm{BuOH}$ extract ( $4.87 \mathrm{~g}$ ) of $N$. hiratsukae and neoruscogenin. The crude extract was divided into two parts, and each was applied to Sephadex-LH 20 column (3/48 cm, $100 \mathrm{~g} ; 100 \% \mathrm{MeOH})$. Fractions $31-46$ and $30-42$, which had NR metabolites, were pooled together for further purification. The combined fraction was subjected to silica gel chromatography $(3 / 27.5 \mathrm{~cm}, 80 \mathrm{~g})$ eluting with gradient of $\mathrm{MeOH}$ in $\mathrm{CHCl}_{3}$ (increasing polarity from 100:0 to $80: 20, \mathrm{CHCl}_{3}: \mathrm{MeOH}$ ) and yielded 25 main fractions. The fraction A precipitated by ACN and $20 \mathrm{mg}$ NR have been recovered. For further purification; fraction B ( $48.5 \mathrm{mg}$ ) was applied to VLC containing reverse phase silica gel (3/ $8 \mathrm{~cm} ; 20 \mathrm{~g})$, eluted with gradient of Acetonitrile: $\mathrm{H}_{2} \mathrm{O}(\% 20-50 \mathrm{ACN})$ to give $\mathbf{6}(11 \mathrm{mg})$ and $\mathbf{1 0}(4 \mathrm{mg})$. The fractions containing metabolite $7(50 \mathrm{mg})$ was subjected to silica gel chromatography $(2 / 17 \mathrm{~cm}$, $15 \mathrm{~g}$ ), and elution with $\mathrm{CHCl}_{3}: \mathrm{MeOH}(90: 10)$ afforded $15 \mathrm{mg}$ of 7.

\subsection{Compound characterization}

$7 \beta, 14 \alpha$-dihydroxy neoruscogenin [Spirosta-5,25(27)-dien$1 \beta, 3 \beta, 7 \beta, 14 \alpha$-tetraol] (1): White amorphous solid. [ $\alpha]_{\mathrm{D}}^{25}$ : -132 (c $0.03, \mathrm{MeOH}$ ). ${ }^{1} \mathrm{H}$ NMR (pyridine- $d 5,400 \mathrm{MHz}$ ): see Table $1 ;{ }^{13} \mathrm{C}$ NMR (pyridine- $d_{5}, 100 \mathrm{MHz}$ ): see Table 2; HR-MS: $m / z 461.2899[\mathrm{M}+\mathrm{H}]^{+}$ $\left(\mathrm{C}_{27} \mathrm{H}_{41} \mathrm{O}_{6}\right.$, calcd. 461.2903).

$12 \beta, 14 \alpha$-dihydroxy neoruscogenin-7-one [Spirosta-5,25(27)dien-1 $\beta, 3 \beta, 12 \beta$-14-tetraol-7one] (2): White amorphous solid. $[\alpha]_{\mathrm{D}}^{25}:-91($ c $0.04, \mathrm{MeOH}) .{ }^{1} \mathrm{H}$ NMR (pyridine- $d_{5}, 500 \mathrm{MHz}$ ): see Table $1 ;{ }^{13} \mathrm{C}$ NMR (pyridine- $d_{5}, 125 \mathrm{MHz}$ : see Table 2; HR-MS: $m / z$ 497.2531 [M+Na $]^{+}\left(\mathrm{C}_{27} \mathrm{H}_{38} \mathrm{O}_{7} \mathrm{Na}\right.$, calcd. 497.2515).

$12 \beta, 21$-dihydroxy neoruscogenin-7-one [Spirosta-5,25(27)dien-1 $\beta, 3 \beta, 12 \beta$, 21-tetraol-7-one] (3): White amorphous solid. $[\alpha]_{D}^{25}:-25$ (c 0.07, MeOH). ${ }^{1} \mathrm{H}$ NMR (pyridine- $\mathrm{d}_{5}, 500 \mathrm{MHz}$ ): see Table $1 ;{ }^{13} \mathrm{C}$ NMR (pyridine- $\mathrm{d}_{5}, 125 \mathrm{MHz}$ ): see Table 2; HR-MS: $\mathrm{m} / \mathrm{z}$ 497.2509 [M+Na ${ }^{+}\left(\mathrm{C}_{27} \mathrm{H}_{38} \mathrm{O}_{7} \mathrm{Na}\right.$, calcd. 497.2515).

$7 \alpha, 12 \beta$-dihydroxy ruscogenin [Spirosta-5-en-1 $\beta, 3 \beta, 7 \alpha, 12 \beta$-tetraol] (4): White amorphous solid. $[\alpha]_{\mathrm{D}}^{25}:-122($ c $0.07, \mathrm{MeOH}) .{ }^{1} \mathrm{H}$ NMR (pyridine- $\left.d_{5}, 500 \mathrm{MHz}\right)$ : see Table $1 ;{ }^{13} \mathrm{C}$ NMR $\left(\mathrm{CD}_{3} \mathrm{OD}\right.$, $125 \mathrm{MHz})$ : see Table 2; HR-MS: $m / z 463.3059[\mathrm{M}+\mathrm{H}]^{+}\left(\mathrm{C}_{27} \mathrm{H}_{43} \mathrm{O}_{6}\right.$, calcd. 463.3060).

$12 \beta, 21$-dihydroxy neoruscogenin-1,7-dione [Spirosta-5,25(27)-

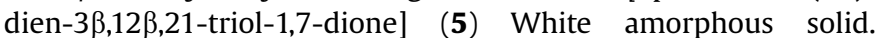
$[\alpha]_{\mathrm{D}}^{25}:-73$ (c 0.03, MeOH). ${ }^{1} \mathrm{H}$ NMR (pyridine- $\mathrm{d}_{5}, 500 \mathrm{MHz}$ ): see Table $1 ;{ }^{13} \mathrm{C}$ NMR (pyridine- $\mathrm{d}_{5}, 125 \mathrm{MHz}$ ): see Table 2; HR-MS: $\mathrm{m} / \mathrm{z}$ 495.2363 [M+Na] ${ }^{+}\left(\mathrm{C}_{27} \mathrm{H}_{36} \mathrm{O}_{7} \mathrm{Na}\right.$, calcd.465.2359).

$12 \alpha$-hydroxy neoruscogenin [Spirosta-5,25(27)-dien-1 $\beta, 3 \beta, 12 \alpha$ triol] (6) White amorphous solid. $[\alpha]_{\mathrm{D}}^{25}:-46$ (c $\left.0.07, \mathrm{MeOH}\right) .{ }^{1} \mathrm{H}$ NMR (pyridine- $d_{5}, 500 \mathrm{MHz}$ ): see Table $1 ;{ }^{13} \mathrm{C}$ NMR (pyridine- $\mathrm{d}_{5}$, $125 \mathrm{MHz})$ : see Table 2; HR-MS: $m / z 445.2950[\mathrm{M}+\mathrm{H}]^{+}\left(\mathrm{C}_{27} \mathrm{H}_{41} \mathrm{O}_{5}\right.$, calcd. 445.2954).

Neoruscogenin-1-O- $\beta$-glucopyranoside [Spirosta-5,25(27)dien-1 $\beta, 3 \beta$,diol-1-O- $\beta$-glycopyranoside (7): White amorphous solid. $[\alpha]_{D}^{25}:-33$ (c 0.07, MeOH). ${ }^{1} \mathrm{H}$ NMR (pyridine- $\mathrm{d}_{5}, 500 \mathrm{MHz}$ ): see Table $1 ;{ }^{13} \mathrm{C}$ NMR (pyridine- $\mathrm{d}_{5}, 125 \mathrm{MHz}$ ): see Table 2; HR-MS: $m / z 613.3353[\mathrm{M}+\mathrm{Na}]^{+}\left(\mathrm{C}_{33} \mathrm{H}_{50} \mathrm{O}_{9} \mathrm{Na}\right.$, calcd. 613.3353).

$7 \beta, 12 \beta$-dihydroxy neoruscogenin [Spirosta-5,25(27)-dien$1 \beta, 3 \beta, 7 \beta, 12 \beta$-tetraol] (8): White amorphous solid. $[\alpha]_{D}^{25}:-118$ (c 0.07, MeOH). ${ }^{1} \mathrm{H}$ NMR $\left(\mathrm{CD}_{3} \mathrm{OD}, 400 \mathrm{MHz}\right)$ : see Table $3 ;{ }^{13} \mathrm{C}$ NMR $\left(\mathrm{CD}_{3} \mathrm{OD}, 100 \mathrm{MHz}\right)$ : see Table 3; HR-MS: $\mathrm{m} / z$ 483.2717 [M+Na] ${ }^{+}$ $\left(\mathrm{C}_{27} \mathrm{H}_{40} \mathrm{O}_{6} \mathrm{Na}\right.$, calcd. 483.2723).

Mixture of $12 \beta$-hydroxy neoruscogenin-7-one and $12 \beta$-hydroxy ruscogenin-7-one [Spirosta-5,25(27)-dien-1 $\beta, 3 \beta, 12 \beta$-triol-7-one and Spirosta-5-en-1 $\beta, 3 \beta, 12 \beta$-tetraol-7-one, respectively] (9a and 9b): White amorphous solid. $[\alpha]_{D}^{25}$ : -91 ( $\left.0.07, \mathrm{MeOH}\right) .{ }^{1} \mathrm{H}$ NMR
( $\left.\mathrm{CD}_{3} \mathrm{OD}, 500 \mathrm{MHz}\right)$ : see Table $3 ;{ }^{13} \mathrm{C}$ NMR $\left(\mathrm{CD}_{3} \mathrm{OD}, 125 \mathrm{MHz}\right)$ : see Table 3; HR-MS: $m / z$ 459.2732 $[\mathrm{M}+\mathrm{H}]^{+}$for 9a $\left(\mathrm{C}_{27} \mathrm{H}_{39} \mathrm{O}_{6}\right.$, calcd.459.2747) $m / z \quad 461.2885 \quad[\mathrm{M}+\mathrm{H}]^{+}$for $\mathbf{9 b} \quad\left(\mathrm{C}_{27} \mathrm{H}_{41} \mathrm{O}_{6}\right.$, calcd.461.2747).

$7 \beta$-hydroxy neoruscogenin 12-one [Spirosta-5,25(27)-dien$1 \beta, 3 \beta, 7 \beta$-triol-12-one] (10): White amorphous solid. [ $\alpha]_{D}^{25}:-142(c$ $0.07, \mathrm{MeOH}) .{ }^{1} \mathrm{H}$ NMR (pyridine- $\mathrm{d}_{5}, 500 \mathrm{MHz}$ ): see Table $3 ;{ }^{13} \mathrm{C}$ NMR (pyridine- $\mathrm{d}_{5}, 125 \mathrm{MHz}$ ): see Table 3; HR-MS: $\mathrm{m} / \mathrm{z} 481.2566$ $[\mathrm{M}+\mathrm{Na}]^{+}\left(\mathrm{C}_{27} \mathrm{H}_{38} \mathrm{O}_{6} \mathrm{Na}\right.$, calcd.481.2566).

\section{Acknowledgments}

This project was supported by Ege University Scientific Research Project 15ECZ011 and partly by TÜBITAK (Project No: 114Z958). We are very grateful to Bionorm Natural Products for providing ruscogenins, and special thanks to Anzarulhaque Anwarulhaque for running NMR experiments at Prince Sattam bin Abdulaziz University.

\section{Appendix A. Supplementary data}

Supplementary data related to this article can be found at https://doi.org/10.1016/j.phytochem.2018.04.002.

\section{References}

Ahmad, M.S., Yousuf, S., Atia tul, W., Jabeen, A., Atta ur, R., Choudhary, M.I., 2017 Biotransformation of anabolic compound methasterone with Macrophomina phaseolina, Cunninghamella blakesleeana, and Fusarium lini, and TNF-alpha inhibitory effect of transformed products. Steroids 128, 75-84.

Asha, S., Vidyavathi, M., 2009. Cunninghamella - a microbial model for drug metabolism studies - a review. Biotechnol. Adv. 27, 16-29.

Baydoun, E., Atia tul, W., Iqbal, S., Smith, C., Choudhary, M.I., 2017. Biotransformation of drospirenone, a contraceptive drug, with Cunninghamella elegans. Steroids $126,30-34$.

Bouskela, E., Cyrino, F.Z.G.A., Marcelon, G., 1994. Possible mechanisms for the inhibitory effect of Ruscus extract on increased microvascular permeability induced by histamine in hamster-cheek pouch. J. Cardiovasc Pharm. 24 $281-285$.

Boyle, P., Diehm, C., Robertson, C., 2003. Meta-analysis of clinical trials of Cyclo 3 Fort in the treatment of chronic venous insufficiency. Int. Angiol. 22, 250-262.

Chen, N.-D., Yue, L., Zhang, J., Kou, J.-P., Yu, B.-Y., 2010a. One unique steroidal sapogenin obtained through the microbial transformation of ruscogenin by Phytophthora cactorum ATCC 32134 and its potential inhibitory effect on tissue factor (TF) procoagulant activity. Bioorg Med. Chem. Lett. 20, 4015-4017.

Chen, N.D., Zhang, J., Liu, J.H., Yu, B.Y., 2010b. Microbial conversion of ruscogenin by Gliocladium deliquescens NRRL1086: glycosylation at C-1. Appl. Microbiol. Biotechnol. 86, 491-497.

Ekiz, G., 2016. Research on Bioactive Secondary Metabolite Profile of Septofusidium Berolinense and Biotranformation of Cycloartane Type Saponins by Endophytic Fungi. Department of Bioengineering. Ege University, Izmir.

EMEA, 2008. Assessment Report on Ruscus Aculeatus L., Rhizoma. EMEA, London. ESCOP, 2003. RUSCI RHIZOMA Butcher's Broom. Thieme, Stuttgart.

Facino, R.M., Carini, M., Stefani, R., Aldini, G., Saibene, L., 1995. Anti-elastase and anti-hyaluronidase activities of saponins and sapogenins from Hedera helix, Aesculus hippocastanum, and Ruscus aculeatus: factors contributing to their efficacy in the treatment of venous insufficiency. Arch. Pharm. 328, 720-724.

Faramarzi, M.A., Badiee, M., Yazdi, M.T., Amini, M., Torshabi, M., 2008. Formation of hydroxysteroid derivatives from androst-4-en-3,17-dione by the filamentous fungus Mucor racemosus. J. Mol. Cat. B Enzym 50, 7-12.

Jawien, A., Bouskela, E., Allaert, F.A., Nicolaides, A.N., 2017. The place of Ruscus extract, hesperidin methyl chalcone, and vitamin $C$ in the management of chronic venous disease. Int. Angiol. 36, 31-41.

Kolet, S.P., Haldar, S., Niloferjahan, S., Thulasiram, H.V., 2014. Mucor hiemalis mediated $14 \alpha$-hydroxylation on steroids: in vivo and in vitro investigations of $14 \alpha$-hydroxylase activity. Steroids 85, 6-12.

Kozlowska, E., Urbaniak, M., Kancelista, A., Dymarska, M., Kostrzewa-Suslow, E. Stepien, L., Janeczko, T., 2017. Biotransformation of dehydroepiandrosterone (DHEA) by environmental strains of filamentous fungi. Rsc Adv. 7, 31493-31501.

Lamm, A.S., Chen, A.R.M., Reynolds, W.F., Reese, P.B., 2007. Steroid hydroxylation by Whetzelinia sclerotiorum, Phanerochaete chrysosporium and Mucor plumbeus. Steroids 72, 713-722.

Muffler, K., Leipold, D., Scheller, M.-C., Haas, C., Steingroewer, J., Bley, T. Neuhaus, H.E., Mirata, M.A., Schrader, J., Ulber, R., 2011. Biotransformation of triterpenes. Process Biochem. 46, 1-15.

Nelson, D.R., 1999. Cytochrome P450 and the individuality of species. Arch. Biochem. Biophys. 369, 1-10. 
Ortiz de Montellano, P.R., Nelson, S.D., 2011. Rearrangement reactions catalyzed by cytochrome P450s. Arch. Biochem. Biophys. 507, 95-110.

Özçinar, Ö., Tağ, Ö., Kivçak, B., Bedir, E., 2016. Microbial transformation of ruscogenins by Cunninghamella blakesleeana. Planta Med. 82, P727.

Piska, K., Zelaszczyk, D., Jamrozik, M., Kubowicz-Kwasny, P., Pekala, E., 2016. Cunninghamella biotransformation - similarities to human drug metabolism and its relevance for the drug discovery process. Curr. Drug Metab. 17, 107-117.

Suryanarayanan, T.S., Thirunavukkarasu, N., Govindarajulu, M.B., Gopalan, V., 2012. Fungal endophytes: an untapped source of biocatalysts. Fungal Divers. 54, 19-30.

Swizdor, A., Kolek, T., Panek, A., Milecka, N., 2012. Selective modifications of steroids performed by oxidative enzymes. Curr. Org. Chem. 16, 2551-2582.

Wang, C., Dong, P.P., Zhang, L.Y., Huo, X.K., Zhang, B.J., Wang, C.Y., Huang, S.S.,
Wang, X.B., Yao, J.H., Liu, K.X., Ma, X.C., 2015. Regio- and stereo-selective oxidation of beta-boswellic acids transformed by filamentous fungi. Rsc Adv. $5,12717-12725$.

Wu, G.W., Gao, J.M., Shi, X.W., Zhang, Q., Wei, S.P., Ding, K., 2011. Microbial transformations of diosgenin by the white-rot Basidiomycete Coriolus versicolor J. Nat. Prod. 74, 2095-2101.

Xiao, X., Liu, X.K., Fu, S.B., Sun, D.A., 2011. Microbial transformation of diosgenin by filamentous fungus Cunninghamella echinulata. J. Asian Nat. Prod. Res. 13, 270-275.

Xu, M., Huo, X.-K., Tian, X.-G., Dong, P.-P., Wang, C., Huang, S.-S., Zhang, B.-J., Zhang, H.-L., Deng, S., Ma, X.-C., 2015. Microbial transformation of diosgenin by Cunninghamella blakesleana AS 3.970 and potential inhibitory effects on Pglycoprotein of its metabolites. RSC Adv. 5, 78081-78089. 